Lingua Rima: Jurnal Pendidikan Program Studi Bahasa dan Sastra Indonesia

Vol. 8 No. 1 Januari 2019

\title{
MODEL PEMBELAJARAN BERBASIS MASALAH MELALUI PENINGKATAN KETERAMPILAN MENULIS TEKS OBSERVASI PADA SISWA KELAS VII SMPN 4 KOTA TANGERANG SELATAN TAHUN PELAJARAN 2016/2017
}

\author{
Dien Mardiana \\ Universitas Pamulang \\ diendiana1107@gmail.com
}

\begin{abstract}
ABSTRAK
Studi ini dilakukan untuk mengetahui peningkatan keterampilan menulis teks observasi melalui pembelajaran berbasis masalah pada siswa kelas VII.8 di SMPN 4 Tangerang Selatan dengan menggunakan Penelitian Tindakan Kelas (PTK). Hasil penelitian menggambarkan bahwa terdapat peningkatan keterampilan menulis teks observasi melalui pembelajaran berbasis masalah. Nilai rata-rata siswa pada kondisi awal hanya sebesar 55,81 dalam kategori kurang namun pada akhir siklus I meningkat menjadi 74,22 pada kategori cukup, dan pada akhir siklus II rata-rata nilai tes siswa sebesar 82,56 termasuk kategori baik. Keaktifan siswa dari siklus I ke siklus II meningkat, pada siklus I rata-rata $68 \%$ dan pada siklus II meningkat menjadi $84 \%$.
\end{abstract}

Kata Kunci: Teks observasi, Pembelajaran Berbasis Masalah

\section{A. PENDAHULUAN}

Guru memiliki peran penting dalam menyukseskan kegiatan pembelajaran agar proses belajar mengajar kondusif dan hasil belajar lebih meningkat. Untuk itu guru perlu menentukan dan merancang persiapan pembelajaran. Skenario pembelajaran harus dipersiapkan dengan matang agar tujuan pembelajaran tercapai. Guru perlu memilih metode, strategi, dan pendekatan yang sesuai dengan materi pelajaran. Tidak hanya itu, media pembelajaran juga harus disiapkan agar proses pembelajaran efektif dan efisian serta terarah mencapai tujuan pembelajaran. Hal ini dilakukan semata-mata untuk keberhasilan peserta didik dalam memahami ilmu, menerapkan, dan membangun konteks berpikir agar menjadi pembelajar yang kritis dan mandiri.

Metode ceramah yang selama ini dilakukan oleh para guru tidaklah efektif untuk menyampaikan materi, menghambat kreativitas dan berpikir kritis karena pembelajaran terpusat pada guru, bahkan membuat peserta didik jenuh sehingga menurunkan perhatian peserta didik dalam proses belajar mengajar. Metode ceramah dan hanya mengandalkan tugas-tugas individu dari buku paket menyebabkan peserta didik tidak menggali potensi dirinya. Mereka hanya menunggu informasi dari guru saja. Ironisnya, masih banyak guru yang menggunakan metode tersebut. Padahal metode searah seperti itu menyulitkan guru mengetahui potensi siswa sebenarnya. Siswa pun tidak dapat mengembangkan kreativitasnya. 
Lingua Rima: Jurnal Pendidikan Program Studi Bahasa dan Sastra Indonesia

Vol. 8 No. 1 Januari 2019

Proses pembelajaran semacam itu tidak memberi kesempatan kepada siswa untuk menuangkan ide, gagasan, atau pemikirannya. Hal ini tentunya akan menghambat proses berpikir kritis. Pada kenyataannya, apabila hal ini berlangsung terus-menerus, maka siswa tidak akan sanggup mengerjakan soal-soal yang terkait dengan dunia luar di kehidupan nyata. Ilmu yang didapat peserta didik hanya bersifat teori. Peserta didik tidak terbiasa mengungkapkan ide-idenya sehingga rasa percaya diri rendah. Kalaupun ada siswa yang berani menjawab, maka pendapatnya hanya memindahkan atau mengopi teori yang didapat dari catatan guru atau yang tertera di buku, bukan menkonstruks sendiri gagasannya.

Dari hasil pengamatan dan wawancara, ditemui beberapa masalah, diantaranya adalah: (1) kesulitan menulis teks laporan observasi, (2) rendahnya kemampuan siswa dalam pemilihan diksi dan ejaan, (3) sulitnya siswa dalam mengorganisasikan teks, (4) rendahnya minat siswa terhadap materi ini pun rendah. Hal ini terlihat dari hasil tulisan peserta didik dan perolehan nilai Bahasa Indonesia yang rendah. Kenyataan seperti itu membuat peserta didik malas mengikuti pembelajaran. Apalagi pembelajaran tidak diramu dengan menarik, tentu semakin membuatnya terpuruk. Kejenuhan terjadi karena guru tidak menyuguhkan pola yang baru, proses pembelajaran memiliki alur yang sama. Pembelajaran yang tepat untuk solusi tersebut yaitu menggunakan metode pemecahan masalah. Metode ini dalam kegiatan pengajaran dengan jalan melatih peserta didik menghadapi berbagai masalah (Arifin dan Haryono, 2016:77). Tujuan penelitian yaitu mengetahui peningkatan keterampilan menulis teks observasi melalui pembelajaran berbasis masalah pada siswa kelas VII.8 di SMPN 4 Tangerang Selatan dengan menggunakan Penelitian Tindakan Kelas (PTK)

\section{B. KAJIAN TEORI}

Seperti yang telah diketahui bahwa pembelajaran merupakan sebuah penentu utama keberhasilan pendidikan. Pembelajaran merupakan proses dua arah yang dilakukan oleh pengajar dan pembelajar. Apalagi pembelajaran bahasa Indonesia yang termasuk pelajaran inti di setiap jenjang pendidikan di Indonesia masih perlu dikembangkan sehingga siswa memiliki keterampilan berbahasa. Pembelajaran bahasa Indonesia bertujuan untuk "meningkatkan keterampilan berbahasa, kemampuan berpikir, dan bernalar serta memperluas wawasan". (Depdiknas: 2003: 4). Agar proses pembelajaran tercapai dengan maksimal diperlukan proses pembelajaran yang partisipatif, aktif, kreatif, efektif, menyenangkan, dan bermakna. Untuk itu, guru harus mengusahakan proses pembelajaran sedemikian rupa. Dengan demikian, akan tercipta 
Lingua Rima: Jurnal Pendidikan Program Studi Bahasa dan Sastra Indonesia

Vol. 8 No. 1 Januari 2019

pembelajaran yang menyenangkan, efektif dalam penyampaian materi, dan memungkinkan siswa mencapai hasil yang optimal.

Strategi dan teknik pembelajaran yang dipilih menjadi tidak variatif. Pembelajaran masih bertumpu pada pembelajaran klasik bersifat konvensional. Pembelajaran seperti itu belum mampu menumbuhkan kebiasaan berpikir produktif. Sebagaiman PP RI No.19/2005 tentang Standar Nasional Pendidikan Bab IV Pasal 19 Ayat 1 :

"Proses pembelajaran pada satuan pendidikan diselenggarakan secara interaktif, inspiratif, menyenangkan, menantang, memotivasi peserta didik untuk berpartisipasi aktif, serta memberikan ruang yang cukup bagi prakarsa, kreativitas, dan kemandirian sesuai dengan bakat, minat, dan perkembangan fisik serta psikologis peserta didik."

Menulis merupakan kemampuan produktif sebab aspek ini menghasilkan karya. Ada proses menciptakan sesuatu. Seperti telah diungkapkan pada pragraf sebelumnya bahwa menulis adalah hasil pengorganisasian pikiran yang diwujudkan dalam bentuk tulisan. Menulis merupakan keterampilan berbahasa yang kompleks karena perlu pengorganisasian isi, Bahasa, pemilihan kosa kata, mencermati pemakaian huruf dan tanda baca dengan berpedoman pada PUEBI (Pedoman Umum Ejaan Bahasa Indonesia). Keterampilan menulis merupakan keterampilan produktif yang harus diimbangi dengan keterampilan membaca. Keduanya saling berkaitan. Dimulai dengan membaca barulah menulis. Dimulai dari mencari sumber dari segala sumber kemudian menuangkan ide-ide.

Model pembelajaran berbasis masalah akan mengarahkan siswa dalam memainkan perannya untuk memggali konsep yang dimiliki dan diterima melalui pembelajaran matematika, sebab pada model pembelajaran tersebut adalah mengutamakan permasalahan yang nyata (Fitrah, 2017:53). Selain itu menurut Sari dan Sugiyarto (2015:155) bahwa proses pembelajaran berbasis masalah dapat membantu peserta didik untuk mengembangkan kemampuan berpikir kritis dan mengaplikasikannya dalam kehidupan sehari-hari.

\section{METODE PENELITIAN}

Pendekatan yang digunakan dalam penelitian ini adalah action research clasroom atau biasa dikenal dengan penelitian tindakan kelas. Objek penelitian ini adalah siswa Kelas VII SMPN 4 Tangerang Selatan Tahun 2016/2017dirancang dan dilakukan seefektif serta seefisien mungkin demi peningkatan keberhasilan peserta didik. Pemilihan waktu dan kelas diatur sedemikian rupa agar tidak mengganggu target pembelajaran selama satu semester.

\section{HASIL PENELITIAN}

\section{Deskripsi Awal Keterampilan Menulis Teks Laporan Hasil Observasi}


Lingua Rima: Jurnal Pendidikan Program Studi Bahasa dan Sastra Indonesia Vol. 8 No. 1 Januari 2019

Sebelum diberi tindakan, siswa diberi tugas oleh guru atau peneliti untuk menulis teks laporan hasil observasi. Kegiatan yang dilakukan adalah membaca teks terlebih dahulu kemudian menulis teks laporan hasil observasi. Kegiatan menulis teks laporan sebelum diberi tindakan bertujuan untuk mengetahui keterampilan menulis teks laporan hasil observasi siswa sebelum dikenai tindakan. Rata-rata perolehan nilai siswa kelas VII.8 adalah 55,81. Perolehan nilai ratarata itu tergambar dari gabungan nilai berupa kualitas isi, organisasi penulisan, dan ejaan serta tata tulis.

Kualitas isi pada saat sebelum dikenai siklus mencapai rata-rata 20,81 dari skor maksimal 35, organisasi penulisan memperoleh 14,66 dari skor maksimal 30, sedangkan ejaan dan tata tulis memperoleh 20,34 dari skor maksimal 35. Setelah dilakukan wawancara, siswa menemui kendala menulis teks laporan hasil observasi karena belum mengetahui bagaimanakah teks laporan hasil observasi yang baik. Oleh Karena pemahaman yang kurang, siswa kurang berminat terhadap materi tersebut. Ini juga berakibat kepada tingkat keaktifan siswa yang rendah karena rasa ingin tahu tidak ada. Selain itu, pemilihan model pembelajaran yang kurang tepat juga sebagai penyebab siswa tidak tertarik belajar menulis teks laporan hasil observasi.

Berdasarkan temuan pada pratindakan atau sebelum diberi tindakan pada siklus 1, maka dipandang perlu dan penting dilakukan perbaikan RPP yang menggunakan model pembelajaran. Maka dibuatlah RPP untuk siklus 1 dengan menggunakan model pembelajaran berbasis masalah. Hal ini dimaksudkan untuk memudahkan siswa menyerap materi dengan baik.

\section{Penerapan Model Pembelajaran Berbasis Masalah untuk Menulis Teks Laporan Hasil Observasi Siklus 1}

Pada bagian ini menyajikan hasil temuan Siklus 1 setelah menerapkan pembelajaran menulis teks laporan hasil observasi melalui model pembelajaran berbasis masalah, meliputi :

1) kemampuan siswa menulis teks laporan hasil observasi dilihat dari kualitas isi teks

2) kemampuan siswa menulis teks laporan hasil observasi dilihat dari organisasi penulisan

3) kemampuan siswa menulis teks laporan hasil observasi dilihat dari ejaan dan tata tulis

Peningkatan hasil teks laporan observasi diharapkan meningkat setelah siklus 1 yang disebabkan oleh perbedaan model pembelajaran yang digunakan sebagai bentuk perlakuan atau tindakan. Pada siklus 1, siswa diminta menulis teks laporan hasil observasi berdasarkan masalah yang ditentukan untuk memancing kreativitas siswa. Hasil temuan siklus 1 memperlihatkan perbedaan dibandingkan hasil nilai saat pratindakan. 
Kemampuan siswa terhadap kualitas isi teks laporan observasi mencapai 25,44, kemampuan siswa akan organisasi penulisan (meliputi: penggunaan kalimat efektif, keterikatan antarkalimat, dan koherensi antarparagraf) memperoleh 22, sedangkan kemampuan siswa akan ejaan dan tata tulis memperoleh 26,28. Ini menunjukkan bahwa siklus 1 menerapkan model pembelajaran berbasis masalah cukup membantu siswa meningkatkan keterampilan menulis teks laporan hasil observasi. Seperti yang ditunjukkan dalam tabel grafik berikut ini.

Diagram 1. Nilai Menulis Teks Observasi Siklus 2

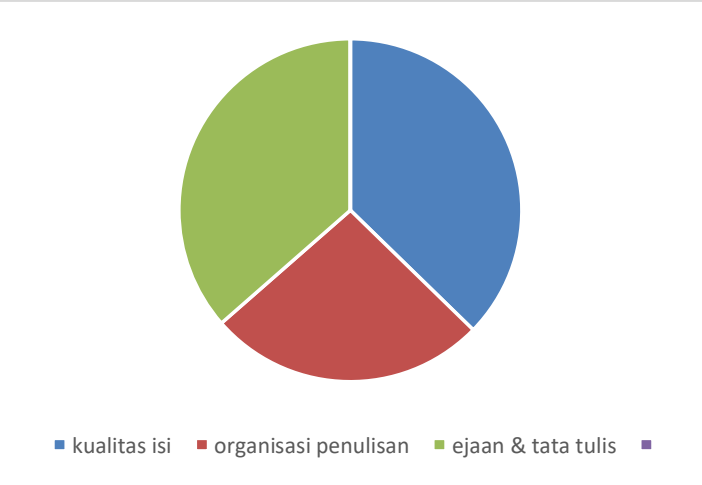

Oleh karena masih ada beberapa siswa yang masih mendapatkan nilai di bawah KKM 77 maka perlu dilakukan siklus 2 agar ada peningkatan nilai dan siswa lebih menguasai materi menulis teks laporan hasil observasi. Tampak pada grafik perolehan nilai menulis teks observasi di kelas VII.8 sebagai berikut:

\section{Grafik 1. Jumlah Perolehan Nilai Teks Observasi Kelas VII}

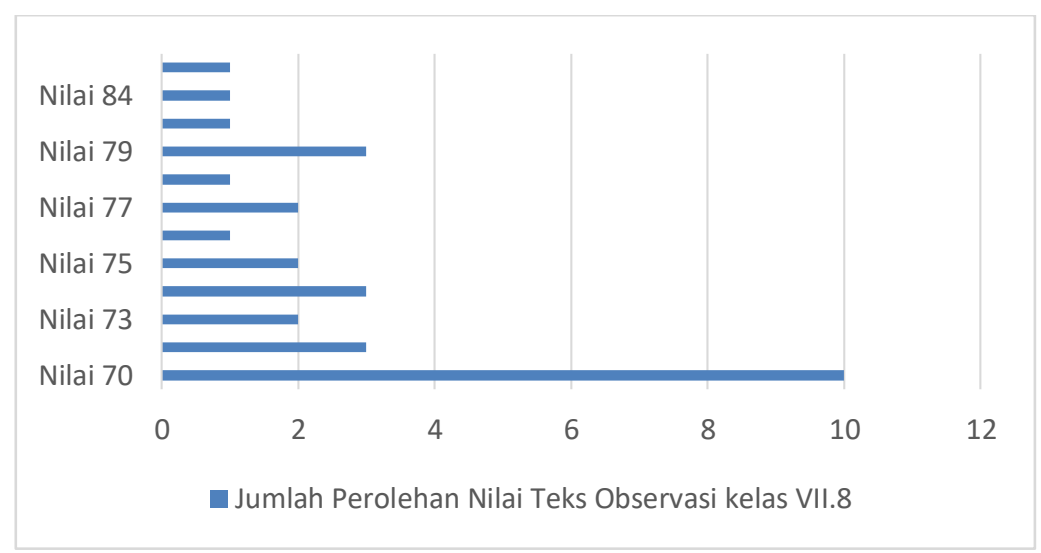


Lingua Rima: Jurnal Pendidikan Program Studi Bahasa dan Sastra Indonesia Vol. 8 No. 1 Januari 2019

Masih terdapat 23 siswa yang memperoleh nilai menulis teks laporan hasil observasi di bawah 77. Untuk mendongkrak nilai tersebut, maka peneliti memperbaiki RPP untuk siklus 2 agar penguasaan siswa terhadap ketiga aspek tersebut lebih tinggi. Dengan demikian, siswa lebih meningkat keterampilan menulis teks observasi.

Hasil observasi keterampilan menulis siswa selama 3 pertemuan di kelas pada siklus 1 menunjukkan perkembangan yang cukup baik. Awalnya, siswa tidak tertarik terhadap pembelajaran menulis teks observasi karena hasil kuesioner menunjukkan 97\%, namun setelah siklus 1 mengalami penurunan sehingga siswa yang tidak tertarik materi pembelajaran menulis teks observasi adalah $26 \%$. Penurunan yang terjadi ini sangat signifikan disebabkan oleh model pembelajaran yang berbeda dari pada sebelum siklus 1 .

Sedangkan catatan lapangan yang diberikan oleh observer menunjukkan bahwa kegiatan pembelajaran menulis teks observasi di kelas VII.8 sudah cukup baik dari kegiatan pendahuluan, inti, dan penutup. Ada catatan lapangan dari observer yang cukup penting dan perlu diperbaiki pada siklus 2, yaitu: pengorganisasian waktu dan beberapa anak yang tertinggal menyimak materi.

Ada beberapa hal yang menjadi penyebab kurang maksimalnya hasil karya siswa berupa cerpen pada siklus 1, yakni: beberapa siswa yang kurang paham dan kesulitan memahami maksud dari perintah tugas sehingga mengganggu keberlangsungan proses pembelajaran. Selain itu, kemampuan siswa akan kalimat efektif, pemilihan kata baku, penggunaan huruf kapital dan ejaan yang tepat serta pemanfaatan tanda baca yang masih lemah. Maka pada siklus 2, untuk menghindari hal tersebut, secara teknis guru akan menyiapkan pembelajaran yang maksimal. Sebelum pengerjaan tugas, memberi kesempatan siswa untuk bertanya memperjelas tentang halhal lain terkait ketiga aspek tersebut dalam menulis teks observasi.

Beberapa temuan di atas akan dijadikan dasar untuk merevisi RPP pada siklus 1 untuk dijadikan RPP pada siklus 2, yaitu mengorganisasikan waktu dengan baik dan cermat. Dalam alokasi waktu perlu perhitungan dengan teliti segala kemungkinan yang terjadi dalam praktik proses pembelajaran. Salah satunya, apabila ada siswa yang terlambat datang atau kurang menyimak pengarahan awal dari guru, agar keterlambatan tersebut tidak menghambat proses pembelajaran saat itu.

Pada RPP siklus 2, alokasi waktu saat kegiatan inti akan ditambah dan kegiatan pendahuluan akan sedikit dikurangi. Anggota kelompok akan diperkecil sehingga mengefektifkan 
Lingua Rima: Jurnal Pendidikan Program Studi Bahasa dan Sastra Indonesia

Vol. 8 No. 1 Januari 2019

diskusi kelompoknya. Anggota kelompok akan diubah sedemikian rupa sehingga lebih heterogen, tetapi saling mendukung.

\section{Penerapan Model Pembelajaran Berbasis Masalah untuk Menulis Teks Laporan Hasil Observasi Siklus 2}

Berdasarkan hasil evaluasi setelah tindakan pada siklus 2, ada peningkatan nilai perolehan rata-rata menulis teks observasi. Rata-rata skor pada siklus 1 berjumlah 74,22 mengalami peningkatan menjadi 82,56. Capaian nilai 82,56 sudah melampaui Kriteria Ketuntasan Minimal Bahasa Indonesia di SMPN 4 Tangerang Selatan.

Capaian nilai rata-rata 82,56 mewakili kemampuan siswa terhadap penilaian mencakup: kualitas isi teks laporan observasi mencapai 27,56, kemampuan siswa akan organisasi penulisan (meliputi: penggunaan kalimat efektif, keterikatan antarkalimat, dan koherensi antarparagraf) memperoleh 24,66 sedangkan kemampuan siswa akan ejaan dan tata tulis memperoleh 30,34. Ini menunjukkan bahwa siklus 2 menerapkan model pembelajaran berbasis masalah sangat membantu siswa meningkatkan keterampilan menulis teks laporan hasil observasi. Seperti yang ditunjukkan dalam tabel grafik berikut ini.

Diagram 2. Nilai Menulis Teks Observasi Siklus 2

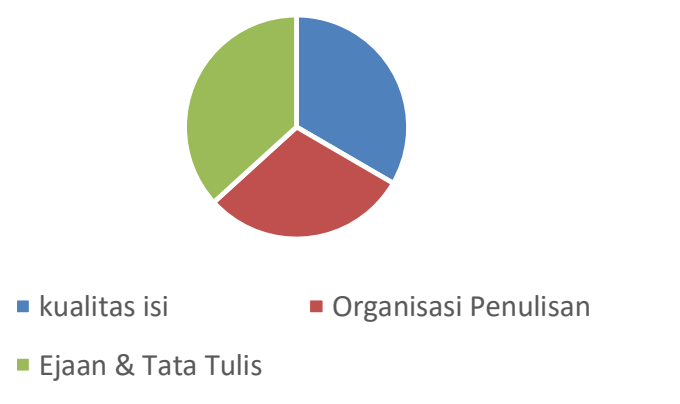

Nilai menulis teks observasi siswa kelas VII.8 SMPN 4 Tangerang Selatan pada siklus sebagai berikut:

Grafik 2. Perolehan Nilai Menulis Teks Observasi Siklus 2 
Lingua Rima: Jurnal Pendidikan Program Studi Bahasa dan Sastra Indonesia

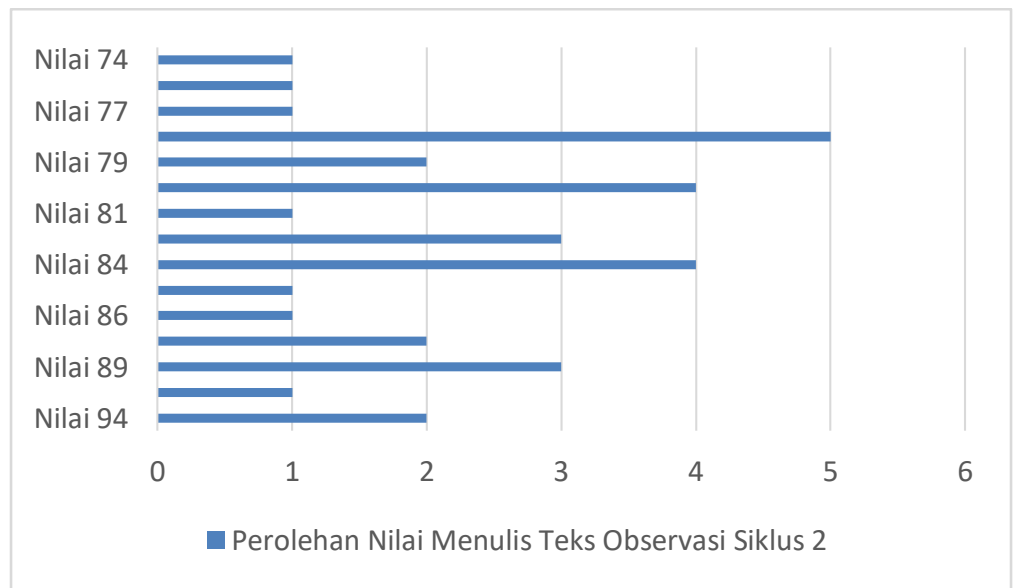

Grafik di atas menunjukkan bahwa perolehan nilai menulis teks observasi siswa kelas VII.8 sangat signifikan. Hasil observasi keterampilan menulis siswa selama 3 pertemuan di kelas pada siklus 2 menunjukkan perkembangan yang sangat baik. Pada siklus 1, siswa yang tidak tertarik terhadap pembelajaran menulis teks observasi ada 26\%, tetapi pada siklus 2 menurun menjadi $12 \%$. Ini membuktikan bahwa siswa yang tertarik mengikuti pembelajaran menuli teks observasi ada $88 \%$. Karena ketertarikkannya siswa membuat pembelajaran menjadi kondusif dan siswa dapat mengikuti dengan baik. Dengan demikian, siswa tidak merasa kesulitan dengan materi tersebut. Seperti pada data yang diperoleh dari kuesioner siswa setelah siklus 2 menunjukkan siswa yang merasa kesulitan hanya 20\%. Siswa sudah menyadari bahwa menulis teks observasi bukan hanya sebagai tugas saja, diperlihatkan oleh data kuesioner $90 \%$ menyatakan bukan hanya bagian tugas guru saja.

\section{Peningkatan Nilai Tes Menulis Teks Observasi Siklus 1 ke Siklus 2}

Peneliti melakukan pengamatan selama siklus 1 dan 2. Pangamatan proses dan pengamatan pada produk hasil siswa dilakukan. Skor penilaian keterampilan menulis teks observasi pada siklus 1 dapat dilihat peningkatannya pada siklus 2.

Tabel 1. peningkatan keterampilan menulis teks observasi dari pratindakan menuju siklus 1.

\begin{tabular}{|l|l|c|c|c|}
\hline No. & \multicolumn{1}{|c|}{ Aspek } & $\begin{array}{c}\text { Rata-rata } \\
\text { prasiklus }\end{array}$ & $\begin{array}{c}\text { Rata-rata } \\
\text { siklus 1 }\end{array}$ & Peningkatan \\
\hline 1 & Kualitas isi & 20,81 & 25,44 & 4,63 \\
\hline 2 & Organisasi penulisan & 14,66 & 22 & 7,34 \\
\hline
\end{tabular}


Lingua Rima: Jurnal Pendidikan Program Studi Bahasa dan Sastra Indonesia Vol. 8 No. 1 Januari 2019

\begin{tabular}{|l|l|l|c|c|}
\hline 3 & Ejaan \& Tata tulis & 20,34 & 26,28 & 5,94 \\
\hline
\end{tabular}

Grafik 3. Hasil Peningkatan Keterampilan Menulis Teks Observasi Siklus 1 dan Pratindakan

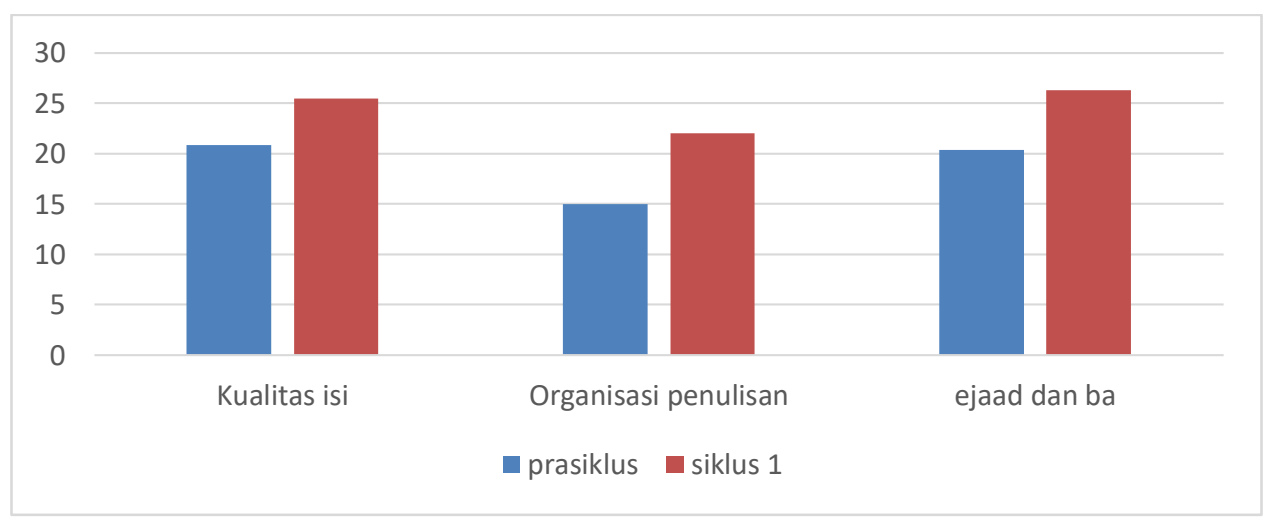

Temuan pada penelitian ini menunjukkan keterampilan siswa menulis teks observasi meningkat dengan signifikan. Hal ini dapat diuji dengan hasil karya siswa berbentuk teks observasi yang dievaluasi dengan Analytical Scoring Robric yang diadaptasi dari Cohen (1994: 328-329). Pada penelitian terdahulu rata-rata skor nilai teks observasi 55,81, silus 1 mencapai 74,22, kemudian siklus 2 menjadi 82,56. Seperti gambar grafik berikut ini.

Grafik 4. Hasil Peningkatan Keterampilan Menulis Teks Observasi Siklus 1 dan Siklus 2

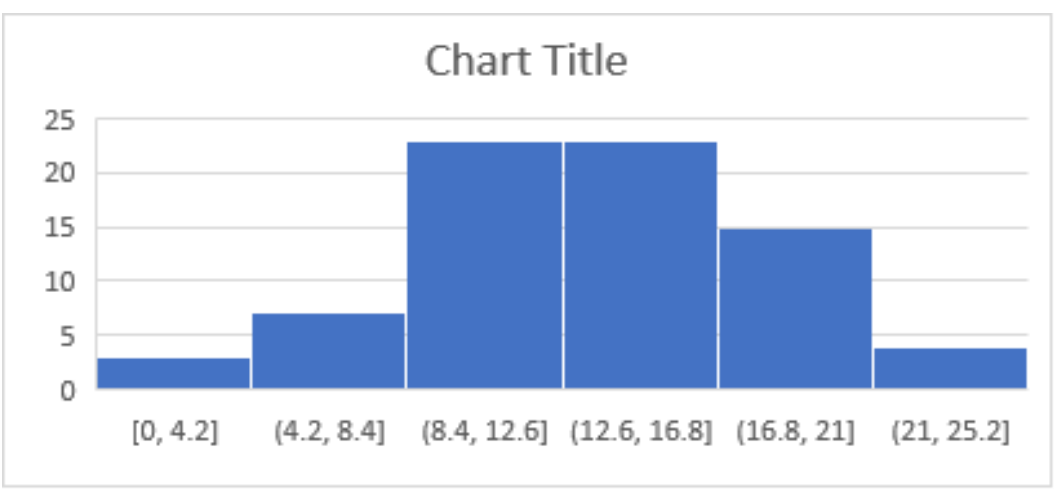

Sehubungan dengan partisipasi siswa dalam proses menulis cerpen, hasil catatan lapangan dari observer menunjukkan peningkatan juga. Peningkatan ini memenuhi kriteria kesuksesan seperti yang dinyatakan oleh gain achievement $15 \%$. Pada penelitian terdahulu $12 \%$, siklus 1 meningkat menjadi 43\%, dan hasil siklus 2 mencapai $65 \%$.

\section{E. SIMPULAN}


Lingua Rima: Jurnal Pendidikan Program Studi Bahasa dan Sastra Indonesia

Vol. 8 No. 1 Januari 2019

Model pembelajaran ini membuktikan bahwa siswa lebih mudah menuangkan ide/gagasannya sehingga dapat menulis teks observasi. Siswa lebih mudah menuangkan ide dan imajinasinya, mudah mengorganisasikan isi cerpen dengan memperhatikan kosa kata dan ejaan. Partisipasi siswa dalam proses pembelajaran pun lebih antusias, semangat, dan kondusif. Proses pembelajaran lebih aktif dan kreatif.

\section{F. DAFTAR PUSTAKA}

Arifin, H.E. Zaenal dan Haryono, Anung. 2016. Metodologi Pengajaran Bahasa dan Sastra. Kota Tangerang:Pustaka Mandiri

Departemen Pendidikan Nasional. 2007. Kamus Besar Bahasa Indonesia. Jakarta: Balai Pustaka.

Fitrah, Muhammad. 2017. Pembelajaran Berbasis Masalah untuk Meningkatkan Pemahaman Konsep Matematika Materi Segiempat. Kalamatika: Jurnal Pendidikan Matematika. Vol 2 No 12017 PP 51-70

http://kalamatika.matematika-uhamka.com/index.php/kmk/article/view/34/33

Sari, Dwi Septiana dan Sugiyarto, Kristian Handoyo. 2015. Pengembangan Multimedia Berbasis Masalah untuk Meningkatkan Motivasi Belajar dan Kemampuan Berpikir Kritis Siswa. Jurnal Inovasi Pendidikan IPA. Universitas Negeri Yogyakarta. Volume 1 No 2 Oktober 2015 PP 153-166

https://journal.uny.ac.id/index.php/jipi/article/view/7501/6496 